\title{
RESPONSABILIDADE ORÇAMENTÁRIA PRECISA DE MELHORIAS
}

Coluna publicada em 12.3.2013: <http://www.conjur.com.br/2013-mar-12/ contas-vista-qualidade-fiscal-responsabilidade-orcamentaria $>$

$\mathrm{Na}$ grande maioria das vezes, quando se tem de sopesar valores, a qualidade é mais importante do que a quantidade e raras são as situações em que se justifica escolha diferente. Assim também ocorre com os gastos públicos.

Trata-se de mais uma entre inúmeras situações em que a qualidade é mais relevante do que a quantidade. Curioso notar que, em geral, isso não é percebido, e muito dinheiro público é desperdiçado por essa razão.

Veja-se que há uma grande disputa por recursos públicos. Órgãos públicos, servidores públicos, empresas privadas, pessoas físicas, enfim, muitos lutando e litigando por mais dinheiro. Observem: por mais dinheiro.

Mas poucas são as vezes em que há movimentos, manifestações, litígios, pelo bom uso do dinheiro público, o que, em ocorrendo, talvez até dispense, ou, com toda a certeza, diminua a incessante busca por mais dinheiro.

É a evidente e equivocada busca pela quantidade, em desconsideração ao que é mais importante: a qualidade.

Como já cheguei a mencionar em coluna anterior (Não falta dinheiro à administração pública, falta gestão, em 31 de julho de 2013), é muito difícil calcular quanto dinheiro público é desperdiçado por falta de uma melhor gestão. Mas é muito fácil saber que é muito, e não tenho dúvidas de que, se cálculo houver, chegará a números impressionantes.

A administração pública já se apercebeu disso, e vê-se que os movimentos em direção a uma gestão pública mais eficiente, com técnicas mais modernas de gestão, associadas a mecanismos de contabilização orçamentária das despesas que favoreçam o gasto público voltado a atender as finalidades para a qual foi destinado, 
apontam na mesma direção. Nota-se, tão somente, uma maior ou menor velocidade de implementação dessas técnicas, quer por países, regiôes, órgãos ou instituições, fazendo com que um melhor uso do dinheiro público fique na dependência da consciência e da competência dos gestores e chefes de Poder, gerando atrasos que só prejudicam aqueles que andam mais devagar.

O sistema de fiscalização financeira e orçamentária, atento à Constituição Federal, que em seu artigo 70 preconiza a fiscalização da legitimidade e economicidade do dinheiro público, e no artigo 37, caput, erige a eficiência à condição de princípio que rege a administração pública, já está há muito tempo desenvolvendo técnicas voltadas a uma fiscalização da qualidade do gasto público. Infelizmente ainda não acolhidas pelos sistemas de fiscalização de todos os entes da federação, essas técnicas certamente serão implementadas num futuro próximo.

Outro passo fundamental nesse sentido é o aperfeiçoamento das normas de elaboração, execução e fiscalização dos orçamentos públicos, hoje estabelecidas basicamente na Lei 4.320, do já longínquo ano de 1964, quando ainda estava em vigor a Constituição de 1946. Moderna para a época, hoje, próxima de completar 50 anos, chega a hora de fazer parte do passado.

A Constituição de 1988 é expressa em seu artigo 165, \$9º ao dizer que "cabe à lei complementar dispor sobre o exercício financeiro, a vigência, os prazos, a elaboração e a organização do plano plurianual, da lei de diretrizes orçamentárias e da lei orçamentária anual", além de estabelecer normas sobre gestão pública e fundos. Já se passaram 20 anos e a referida lei ainda não foi publicada. A utilização, por recepção, no que é compatível, da Lei 4.320, evidentemente não é a melhor solução, deixando lacunas importantes, como a regulamentação do plano plurianual, inexistente à época.

Projetos em tramitação no Congresso Nacional, já alcunhados de "Lei de Qualidade Fiscal" e "Lei de Responsabilidade Orçamentária", estão em curso com vistas a substituí-la por uma nova lei, mais moderna, contendo novas regras que modernizam o sistema orçamentário brasileiro, consolidando técnicas voltadas a favorecer a qualidade do gasto público, permitindo mais investimentos públicos e despesas na área social.

São muitos os desafios da nova lei que abrangem medidas no âmbito do planejamento, na gestão, na contabilidade pública, na transparência e na fiscalização.

Modificações na contabilização orçamentária, com o aperfeiçoamento dos programas, construídos de forma que sejam voltados a resultados claros e mensuráveis por indicadores precisos e confiáveis, contextualizados em um sistema de planejamento da ação governamental que permita aos atores públicos e privados 
terem uma visão segura do que se espera do poder público, são algumas das medidas que integram esse necessário avanço na legislação vigente. Tornar definitivas regras de elaboração e execução orçamentárias, por norma aplicável de maneira uniforme a todos os entes da federação, garantindo maior segurança jurídica a regras que são atualmente veiculadas por leis de diretrizes orçamentárias (individualizadas para cada unidade federada e de caráter temporário), é também medida importante da nova legislação. É o caso, por exemplo, das regras para as hipóteses de anomia orçamentária, quando o orçamento não é aprovado no prazo, tema abordado em $E$ o ano começa sem a aprovação do orçamento federal, nesta edição, p. $169-172$.

São necessárias, e os projetos as contemplam, normas para uniformizar e estabelecer limites para a execução orçamentária, especialmente nos restos a pagar, evitando que os pagamentos se prorroguem para o exercício seguinte e prejudiquem o planejamento, controle e transparência dos gastos. Ainda na execução orçamentária, há que se definir com mais clareza e precisão o grau de impositividade dos nossos orçamentos, criando mecanismos para tornar o orçamento executado o mais próximo possível daquele que foi aprovado.

Definir e padronizar a contabilização das receitas e despesas, seguindo padrões internacionais e estabelecendo limites e regras claras, de modo a dificultar ao máximo manobras de "contabilidade criativa" que contornem a legislação por caminhos tortuosos, são outras medidas que se impõem.

Há que se destacar também a importância da criação, aperfeiçoamento e sistematização de mecanismos de cooperação intergovernamental, cada vez mais necessários à execução de políticas públicas que dependem da ação conjunta de vários entes da federação, tanto no financiamento quanto na operacionalização, evitando que o interesse público fique sujeito às alternâncias de governos, muitas vezes de partidos e ideologias diferentes, que são transitórios, e cujos atritos possam impedir, dificultar e atrasar a implementação de políticas públicas voltadas a atender necessidades fundamentais da população.

Não há também como aguardar mais para melhorar e modernizar mecanismos de fiscalização e controle das políticas públicas, aferindo sua economicidade, eficiência, eficácia e efetividade, quer sejam executadas diretamente pelo poder público, quer sejam delegadas a entidades do terceiro setor, evitando o desvio de recursos do orçamento para instituiçóes inidôneas e sem compromisso com o bom uso do dinheiro público.

Aperfeiçoar a qualidade do gasto público é fazer mais com menos, ou seja, produzir mais benefícios públicos com menos recursos, o que exige, entre outras 
medidas além das já mencionadas, a modernização da gestão, aumento da participação popular nas decisóes sobre o gasto público, maior transparência e controle. São inúmeras as providências a serem tomadas nesse sentido, que exigem não somente uma nova legislação, adaptada aos novos tempos e técnicas, mas também, e principalmente, uma mudança de cultura na administração pública. No mais das vezes preocupada com aspectos formais da despesa pública, a burocracia acaba perdendo o foco naquilo que realmente importa, que é atender a necessidade pública, transformando-se numa verdadeira "burrocracia", de todos conhecida e odiada.

Como se vê, são muitos os desafios. Projetos de lei já existem, o sistema de fiscalização financeira está se aperfeiçoando nesse sentido. Resta apenas uma maior conscientização, apoio e ação firme da população para incentivar a implantação de uma nova perspectiva na administração pública e seus gestores, voltando-os a um gasto público de qualidade. 